\title{
POSITIONING OF CROWDFUNDING PLATFORMS: TURKEY AS AN EMERGING MARKET CASE
}

\author{
DOI: 10.17261/Pressacademia.2019.1036 \\ JMML- V.6-ISS.2-2019(3)-p.84-94 \\ Melek Demiray ${ }^{1}$, Sebnem Burnaz ${ }^{2}$ \\ ${ }^{1}$ Istanbul Technical University, Department of Management Engineering, Istanbul, Turkey \\ demirayme@itu.edu.tr, ORCID: 0000-0002-5147-0809 \\ ${ }^{2}$ Istanbul Technical University, Department of Management Engineering, Istanbul, Turkey \\ burnaz@itu.edu.tr, ORCID: 0000-0002-4845-4031
}

Date Received: May 10, 2019

Date Accepted: June 12, 2019

To cite this document

Demiray, M., Burnaz, S. (2019). Positioning of crowdfunding platforms: Turkey as an emerging market case. Journal of Management, Marketing and Logistics (JMML), V.6(2), p.84-94 DOI: 10.17261/Pressacademia.2019.1036

Permenant link to this document: http://doi.org/10.17261/Pressacademia.2019.1036

Copyright: Published by PressAcademia and limited licenced re-use rights only.

\begin{abstract}
Purpose - Crowdfunding, as a novel concept, offers an alternative funding method that enables entrepreneurs to realize their original ideas. The aim of this study is to understand how crowdfunding platforms can be positioned in an emerging crowdfunding market.

Methodology - Turkey was chosen as a developing market which presents a real potential with newly regulated crowdfunding environment and rapidly flourishing entrepreneurship ecosystem. The analysis proposes a positioning map of crowdfunding platforms depending on two main dimensions: the level of complexity based on regulatory procedures and the level of expertise based on project categories.

Findings- Introducing positioning concept into crowdfunding literature broadens understanding of this phenomenon and contributes to the development of assessment criteria for crowdfunding platforms.

Conclusion- Platform managers who desire to develop their positioning strategy upon gaps in the crowdfunding market by differentiating their features in order to get advantages over their rivals can benefit using the proposed positioning map analysis.
\end{abstract}

Keywords: Crowdfunding, crowdfunding platform, positioning, emerging market, entrepreneurship JEL Codes: M13, M30, M31

\section{INTRODUCTION}

Sharing economy and community effect have changed the way of doing business in the digital era. The concepts of 'co-creation', 'co-funding' and 'peer-to-peer' become inevitable parts of sustainable innovation and entrepreneurship. Crowdfunding, as a novel financial system, has emerged to facilitate accessing funds and democratize the entrepreneurial ecosystem. Crowdfunding is basically gathering a small amount of money from a large number of people, namely the 'crowd' in a community or in a society to realize a specific project. Especially, social entrepreneurs and early stage start-up organizations that generally face with difficulties in raising capital from traditional funding mechanisms including banks, angel investors and venture capitals (VCs), can effectively and efficiently benefit from this newly emerging financial system. Due to the power of collectivism through the sense of community, crowdfunding provides much more than capital for enterprises. Indeed, individuals, entrepreneurs and start-ups can find the opportunity to use crowdfunding as a marketing research tool by asking their prospective customers for their opinion about certain project or product, testing features and market acceptance of the project or new product as well. Crowdfunding market has rapidly spread around the world in recent years rising from \$34.4 billion in 2015 (Massolution's 2015 CF Industry Report, 2015) to almost \$73 billion in 2018 (Technavio, 2018), increasing by more than twice within three years. This 
growth has initially depended upon the emergence and enhancement of crowdfunding platforms which operate as online settings to create relationships, enable connectivity and coordinate transactions among all actors of the system. Due to the vital role of the platform, to select the appropriate medium is crucial for the success of the crowdfunding campaign (European Commission Report, 2013). Despite the significance of the crowdfunding platform selection, there is a lack of studies on evaluation criteria of the crowdfunding platforms. To address this research gap, this paper proposes a positioning map to serve to assess crowdfunding platforms. Two main distinctive features of the crowdfunding platforms are presented as dimensions of the positioning map. This study represents the first effort to provide a holistic view in an emerging crowdfunding market. Turkey is an emerging market case because of its newly regulated and developing crowdfunding market based on rapidly growing entrepreneurial ecosystem.

The following section reviews the relevant literature by elaborating on the crowdfunding concept and various models. The third section provides information and data about the progress of the global crowdfunding market and emerging crowdfunding market in Turkey. Then, the methodology of the study is clarified by offering a positioning map for the crowdfunding platforms for a certain market. Also, the conceptualizing of the positioning map is explained through the distinctive attributes of the platforms. In the next section, the positioning map of crowdfunding platforms in Turkey is offered based on the evaluation of each platform using secondary data. The final section concludes with theoretical and managerial implications through the discussion of the findings and limitations and future research suggestions are presented as well.

\section{CROWDFUNDING CONCEPT AND MODELS}

Crowdfunding concept originates from the broader approach of crowdsourcing in which 'crowd' is used for the sources of creative ideas, feedbacks, comments and suggestions for the design and improvement of innovative products or business processes (Belleflamme, Lambert and Schwienbacher, 2014). Lambert and Schwienbacher (2010, p. 6) identify crowdfunding as: "An open call, essentially through the Internet, for the provision of financial resources either in form of donations or in exchange for some form of reward and/or voting rights in order to support initiatives for specific purposes." (cited in Macht and Weatherston, 2014). The actors of the crowdfunding mechanism are regarded as project owners (entrepreneurs or initiators of the campaigns), funders (donors, backers or investors of the projects) and platform managers (Gerber, Hui and Kuo, 2013, 2013; Ordanini, Meceli, Pizeli and Parasuraman, 2011). The crowdfunding platforms bring members together to raise capital and provide required information about projects through online settings. Project creators have the chance to introduce their initiatives to prospective supporters and get funded. Thanks to the digitalization, a great number of individuals can effectively benefit from platforms at a low cost as creators and/or supporters (Kuti and Madarász, 2014). The framework of crowdfunding models is grouped into two primary categories as the nonfinancial return models and the financial return models, each including two types (European Commission Report, 2013). These crowdfunding models are described as donation-based, reward-based, lending-based and equity-based depending on the type of return offered to potential funders (Buysere, Gajda, Kleverlaan and Marom, 2012; Bretschneider, Knaub and Wieck, 2014).

Donation-based crowdfunding includes the projects where funders do not have any expectation including financial or nonfinancial return (Kuti and Madarász, 2014; Mollick, 2014). Crowdfunding projects can range from pure charity-based to the ones based on personal reasons such as education, research, art and travel. The achievement of a donation-based crowdfunding project is closely associated with emotional factors or common good (European Commission Report, 2013). The major motive of the funders is philanthropy since they do not receive a material return for their financial support in this type (Marom and Sade, 2014). Considering the psychological aspect, when a funder receives a thank-you note from a campaign owner, he/she gets personal satisfaction (Meric, Bouiass and Maque, 2015) since the funder has the opportunity to make a difference in one's life. In addition, non-governmental organizations (NGOs) generally launch this type of crowdfunding campaigns to raise money for specific causes. If the donors believe the benefit of the projects, they are willing to give large amounts of money. Also, when the NGO regularly informs the donors about the progress of the project, it has more loyal donors since providing up-to-date information is critical to create long-term and strong relationship with funders (Buysere et al., 2012). Gofundme, top crowdfunding platform in the world, operates as a donation-based model and has more than 50 million funders and total $\$ 5$ billion funding volume. As for another non-financial return model, in reward-based crowdfunding, funders finance a campaign by expecting tangible or intangible offerings in exchange. The reward can be in the way of nonmonetary material like the actual product, DIY kit, creative experiences (e.g., a visit to the film set, a phone call from the writer, lunch with the band) or immaterial such as providing reputation and giving supporter's name to a hero in a game (Cholakova and Clarysse, 2015; Kuppuswamy and Bayus, 2014). Additionally, reward-based crowdfunding gives an opportunity to the supporters as first buyers, providing them receive created products by supported projects in the earlier stages, at a reduced price and/or with other extra 
advantages. The "pre-sales of the product" to an early adaptor is widely used in this kind of projects which is also convenient for enterprises which produce new software and hardware (Mollick, 2014) and also music albums (Marom and Sade, 2014). Besides financing the project in advance, reward-based crowdfunding and especially its pre-sales form allow an entrepreneur to get an insight about demand estimation relating the output of the project and conduct marketing research by analyzing the feedbacks of the (potential) supporters. Reward-based crowdfunding can be related to a wide variety of project categories including animals, art, business, comics, crafts, dance, design, education, environment, fashion, film/video, food, games, journalism/media, health, music, photography, sports, technology, theater. Kickstarter and Indiegogo that serve in such a broad range of categories are the leading reward-based crowdfunding platforms in the world. When it comes to the financial return models, lending-based crowdfunding in which funds are offered as loans, is the most common model around the world. Funders provide money for a limited time by having an expectation of repayment. While in some lending-based crowdfunding platforms investors are paid interest, in other cases they get only the amount of capital they loan (Marom and Sade, 2014). Lending-based crowdfunding model has a well-known type called peer-to-peer (P2P) lending where investees and investors generally do not know each other and matching of these actors is made by the platform. Although some platforms act as intermediaries to establish a relationship between these two actors, other platforms act as middlemen and pay back the funds to the lenders (Buysere et al., 2012). The primary advantage of this crowdfunding model is that it enables an enterprise or an individual to take a loan from a society without using the banking system. The interest rate is usually determined based on the perceived risk of the investee; however, it is generally much more than the interest income that a lender can receive from a bank, but less than a conventional loan applicable for the borrower (Kirby and Worner, 2014). This kind of crowdfunding model is secured since it attracts investors who desire to receive a return on investment in a short time. In addition, lending-based crowdfunding can be used instead of the traditional lending mechanism by the initiatives which have inconsistent spending and revenue period and that want to maintain the sustainability of their business processes. Indeed, lending-based crowdfunding platforms provide opportunities for social lending by enabling loans to social entrepreneurs with lack of interest and small businesses in underdeveloped regions as microfinance (Buysere et al., 2012).

Equity-based crowdfunding, as another financial return model, proposes a deal for distribution of shares and a revenue sharing option to investors (Cholakova and Clarysse, 2015) where they can get stocks of start-ups/companies with a small amount of investment through an open call on the online platforms (Ahlers, Cumming, Guenther and Schweizer, 2012). This type of crowdfunding model involves the sales of equity for capital (Bradford, 2012) which is very similar to angel investment and VC. However, in this model, a funder makes an investment to an enterprise for receiving a pre-determined percentage of equity or shareholding. An initiative shares information on the platform's website about the general idea of the business, team, the tentative business plan, marketing and financial data related to the firm and industry and the percentage of the equity offered (Crowdfunding's Potential for the Developing World, 2013). Equity-based crowdfunding can be convenient and a significant source for start-ups and SMEs that face with problems to find money from traditional funding mechanism like banks, angel investors, VCs and government programs (Kuti and Madarász, 2014). This kind of crowdfunding model rather than the lendingbased one is suitable for innovative initiatives (Buysere et al., 2012) such as software, game, film, music, publishing (Mitra, 2012). In addition, enterprises which serve in a variety of industries including food/beverage, consumer products, telecommunication, technology and e-commerce can use equity-based crowdfunding. The main drawback of this model is high failure rate of young start-ups where a funder must take a risk of loss or a long waiting time to receive any income concerning his/her investment (Crowdfunding Industry Report, 2013). Equity-based crowdfunding has become popular after it was regulated in the USA in 2012 with the Jumpstart Our Business Startups (JOBS) Act. Germany, the U.K., Ireland, France, the Netherlands, Switzerland and Australia are other countries in which crowdfunding platforms are allowed to sell equity to investors with a small amount of money (Ahlers et al., 2012). Regulatory procedures of the equity-based crowdfunding are mainly shaped by the legislation of the home country (Heminway and Hoffman, 2010).

\section{CROWDFUNDING MARKET}

The crowdfunding system has become an alternative financing mechanism to traditional investment methods including VCs, angel investments and banking. Moreover, it is accepted as leverage to support innovation, entrepreneurship and employment by facilitating monetary access and strengthening social network (Milosevic, 2015). According to the Massolution's $2015 \mathrm{CF}$ (Crowdfunding) Industry Report, the global crowdfunding markets have raised from \$6.1 billion in 2013 to \$34.4 billion in 2015. It is forecasted that total global crowdfunding funding volumes would reach up to $\$ 73$ billion in 2018 (Technavio, 2018). Although World Bank (2013) had predicted that it would reach $\$ 96$ billion by 2025 (Crowdfunding's Potential for the Developing World, 2013), it is seen that crowdfunding market in the world has an accelerated expansion rate that is more than previous prospective volume since recent research claims that global crowdfunding market is expected to grow to $\$ 162.47$ billion by 2022 
(Technavio, 2018). Concerning the crowdfunding platform quantity, although there is no precise information, it is predicted that more than 2000 crowdfunding platforms currently operate in the world. As for the global crowdfunding market by models, lending-based crowdfunding reached the vast majority of market share as $76 \%$ in 2017 , while the percentage of reward and donation-based crowdfunding market in total was $16 \%$ and equity-based crowdfunding had relatively small market share with $8 \%$ (Statistica, 2017). Market share and growth rate of equity-based crowdfunding is expected to rise rapidly since the number of countries which organize regulations on this kind of crowdfunding model has increased and also some European Union countries are planning to set rules in order to enable equity-based crowdfunding platforms can operate across other EU regions. According to Technavio (2018), there are three key countries holding the majority share of the global crowdfunding market in 2017. US is the global leader with the dominant market share (45\%), followed by China and the UK.

\subsection{Crowdfunding in Turkey as an Emerging Market}

Entrepreneurship is rapidly increasing and presents a huge potential in Turkey since it is regarded as a stimulant of innovation and a provider of steady employment opportunity (Global Entrepreneurship Monitor Report, 2019). In addition, it is seen as one of the main drivers of economic growth based on the fact that improving the conditions for entrepreneurship by $10 \%$ could raise \$331 billion to the economy (Global Entrepreneurship Index Report, 2017). Therefore, entrepreneurship is encouraged and supported by government, universities and many stakeholders in Turkey. However, the low accessibility of capital is one of the significant problems for entrepreneurs. Although Turkey has a variety of financial mechanisms including banks, angel investors and VCs, entrepreneurs encounter difficulties in getting fund to realize and maintain their projects. Government funds have the dominant market share by the funding volume of $\$ 71$ million whereas angel investments and VCs have less volume by the amount of \$25.7 million for funding early phase startups in 2018 (Startups.watch, 2019).

Crowdfunding, as a novel concept, offers an alternative funding method that enables entrepreneurs to access capital in a feasible manner. Although crowdfunding as a mechanism launched in 2010 in Turkey, it is in its nascent phase in comparison to developed crowdfunding markets in the USA and Europe. Crowdfunding activities in Turkey had been relatively limited since the issue of crowdfunding was not characterized by the Capital Market Board (SPK) which is the authorized governmental institution to regulate financial systems. In 2017, Crowdfunding Association in Turkey was established to accelerate the process concerning the regulation and encourage widespread use of crowdfunding platforms that provide alternative funding opportunities for the entrepreneurship ecosystem. With the contribution of Crowdfunding Association, on December 5, 2017, crowdfunding was legally accepted under the Capital Market Law and crowdfunding platforms were entitled to act as intermediate in crowdfunding activities by getting a license from Capital Market Board in Turkey. On the other hand, the scope of this regulation was limited since only the description of the crowdfunding concept and fundamental characteristics of a crowdfunding platform had been given. Therefore, it is necessary to publish secondary legislation to clarify rules and procedures with regard to crowdfunding. As an effort to accomplish this requirement, Draft Communique on Equity-Based Crowdfunding was released for one-month public comment and review period by the Capital Market Board on January 3, 2019. While equity-based crowdfunding platforms are regulated under the Draft Communique, lending-based crowdfunding and also real estate crowdfunding in Turkey are firmly forbidden. However, Draft Communique does not enact rules and procedures concerning donation and reward-based crowdfunding activities and platforms.

Draft Communique on Equity-Based Crowdfunding provides most of the crucial key points for platform managers, entrepreneurs and investors who are the main actors of this novel funding system. From the platform management perspective, the Draft Communique sets the rules and procedures about how a platform gets the license, establishes committees for supervising the activities and selecting crowdfunding projects, conducts required membership activities, organizes fund collection and transfer and provides detailed information concerning the activities to the Capital Market Board. Moreover, this Draft Communique regulates activities and responsibilities of entrepreneurs such as what kind of information they have to submit to their potential investors, the duration of crowdfunding campaign, the requirements of launching a company and reaching target funding amount, the usage of the funds, the scope and frequency of the announcements about their start-ups activities and tax issues. As for the investor aspect, Draft Communique regulates investments activities by making a distinction between qualified and non-qualified investors to be able to adequately protect the rights of investors. While there is no limit about the investment amount for qualified investors, non-qualified investors can annually invest maximum TR 20,000. Moreover, all investors have to sign risk agreement since the nature of start-up investment includes risk due to high start-up business failure rate. On the other hand, a notable criticism to Draft Communique on Equity-Based Crowdfunding is the uncertainty regarding the secondary market which might discourage potential investors to invest their money to the crowdfunding projects. 
As of today, donation and reward-based crowdfunding platforms has been actively operating in Turkey. These are Arıkovanı, Buluşum, Crowdfon, Fonbulucu, Fongogo and Ideanest. Bi'Ayda, Ortagız and ProjemeFon were platforms that exited from the crowdfunding market in Turkey. However, ProjemeFon was purchased and has named as Crowdfon in 2013. Until the end of 2017, 867 crowdfunding projects had been published in these platforms and the crowdfunding market size was TR 20.149.365.000 (Unsal, 2017). By the end of 2018, approximately 300 projects were successfully funded out of more than 900 published crowdfunding projects and almost TL 8 million was pledged. Based on this information, it can be seen that the success rate of crowdfunding projects is $30 \%$ in Turkey. As a developing crowdfunding market, there are a few equity-based crowdfunding platforms that have been established as informal and waiting for finalizing the legislative process of equity-based crowdfunding by Capital Market Board to launch officially and actively their operations in Turkey. These platforms are StartupFon, Fongogo Pro and Fonbulucu.com Invest. Detailed information will be given about platforms in Turkey in the following section.

\subsection{Proposed Positioning Map for Crowdfunding Market in Turkey}

The concept of positioning which is critical component in marketing, branding and strategy (Aaker, 1996; Hooley, Piercy and Nicoulaud, 2008; Kapferer, 2012; Keller, 2012; Porter, 1996) can be used for crowdfunding platforms to clarify the perception that certain platforms create in the minds of actors of this novel system including entrepreneurs as potential project creators, funders/investors and managers of other platforms. In addition, a positioning strategy that ensures competitive superiority is a key point to the success of a company or a brand (platform here) (Wen and Yeh, 2010). Crowdfunding platforms that properly build their positioning strategy against their competitors can take advantages by differentiating their attributes from other platforms. Positioning map can be used by platform managers to discover gaps in the market and guide their activities. In this study, platforms are displayed as points assessed based on two distinct attributes as dimensions shown in the positioning map (Figure 1). These main dimensions offered by authors of this study to conceptualize positioning of the crowdfunding platforms are the level of complexity based on regulatory procedures and the level of expertise based on project categories. Since Turkey was selected as an emerging market case in this study, all types of crowdfunding models cannot be displayed in a positioning map. As a result of the upcoming legal crowdfunding arrangement in Turkey in which lending-based crowdfunding is forbidden, there is no platform adopting lending-based crowdfunding model. Besides, equity-based crowdfunding platforms that have not actively operated in Turkey due to incomplete legislation process are displayed based on information that is provided through their beta-version websites and declarations of platform managers about the objectives of their platforms.

The first dimension of the positioning map, represented on the X-axis, is determined as the complexity level of regulatory procedures. Crowdfunding models have different levels of complexity concerning funding processes, procedures and regulatory arrangements related financial transaction structure (Hemer, 2011). While the donation-based model has the simplest procedure and process in comparison to the others, equity-based crowdfunding is the most complicated among all other kinds of models. Moreover, lending-based crowdfunding is more sophisticated than reward-based due to its tight capital acquiring mechanism. The X-axis of the positioning map provides critical insights about platforms such as a platform's target market depending on the typology of project creators and funders, motivational aspect, the stage of entrepreneurial activity, the amount of capital need, the degree of risk perception and the type of funding mechanism. In the donation-based model including the simplest procedures, project creator of crowdfunding campaigns are mostly individuals, charities and non-profit organizations. Therefore, in the less sophisticated level, funders desire to help the (social) causes and philanthropy is the main motivation for funding. Despite non-financial characteristic of reward-based crowdfunding models, generally, some tangible rewards such as products produced as the outcome (i.e. a DIY tool, an album, or a gala ticket for a supported film) are delivered to funders in this model (Mollick, 2014). Although both lending-based and equity-based models are used to receive the maximum financial return, the degree of risk perception in equity-based crowdfunding model is more than of lending-based one (Kuppuswamy and Bayus, 2014). In general, while the level of complexity is increasing, the monetary return expectancy and risk perception are getting high from the funders' perspective. In addition, less complex crowdfunding models are adopted in the early phases of entrepreneurial projects where less amount of capital is required (Braet, Spek and Pauwels, 2013). In fact, less sophisticated crowdfunding models can benefit from both "keep-it-all" funding mechanism which allows project creators to keep any amount of pledged money regardless of whether the funding goal is met at the end of project duration and the "all-ornothing" funding mechanism where entrepreneurs target a certain amount of fund that must be raised within a project period and the creator gets no money unless the funding goal is not reached (Gerber et al., 2013). 
As for the other dimension of the positioning map, the level of expertise based on project categories is represented on the $\mathrm{Y}$ axis. Concerning this attribute, types of crowdfunding platforms are evaluated based on the scope of project categories that are accepted for publication. The crowdfunding ecosystem encompasses primarily two types of platforms: horizontal and vertical (Demiray, Burnaz and Aslanbay, 2017). Multicategory platforms, called as "horizontal platforms", offer a broad basis for all kind of crowdfunding initiatives including animals, art, comic, community, dance, design, education, environment, fashion, film, food, gaming, health, music, photography, politics, religion, small business, sports, technology, theater, transmedia, video/web and writing. On the other hand, single category platforms or specialized ones called as "vertical platforms", may focus and serve less or single kind of crowdfunding projects. Vertical platforms are field, project category or industry centric and attract people with similar interest and motivations. In the music industry, vertical crowdfunding platforms are becoming popular since they allow novel and experienced artists to gather money directly from public to release their albums and also fans have the chance to contribute in the production stage of the albums of their favorite artists (Ordanini et al., 2011). As expected, vertical platforms are most likely to build their own community due to common interest of these groups and high social identification within group (Demiray and Aslanbay, 2017).

\section{CROWDFUNDING PLATFORMS IN TURKEY}

In this section, analysis about active crowdfunding platforms adopting non-financial models as donation and reward-based are presented, such as Arıkovanı, Buluşum, Crowdfon, Fonbulucu, Fongogo and Ideanest and positioning map of crowdfunding platforms in Turkey is proposed in Figure 1. Also, active crowdfunding platforms in Turkey and their characteristics are summarized in Table 1 based on the data available on platforms' web site at the end of 2018. Last, information related equitybased crowdfunding platforms including Fongogo Pro, Fonbulucu.com Invest and StartupFon are provided.

Figure1: Positioning Map of Crowdfunding Platforms in Turkey

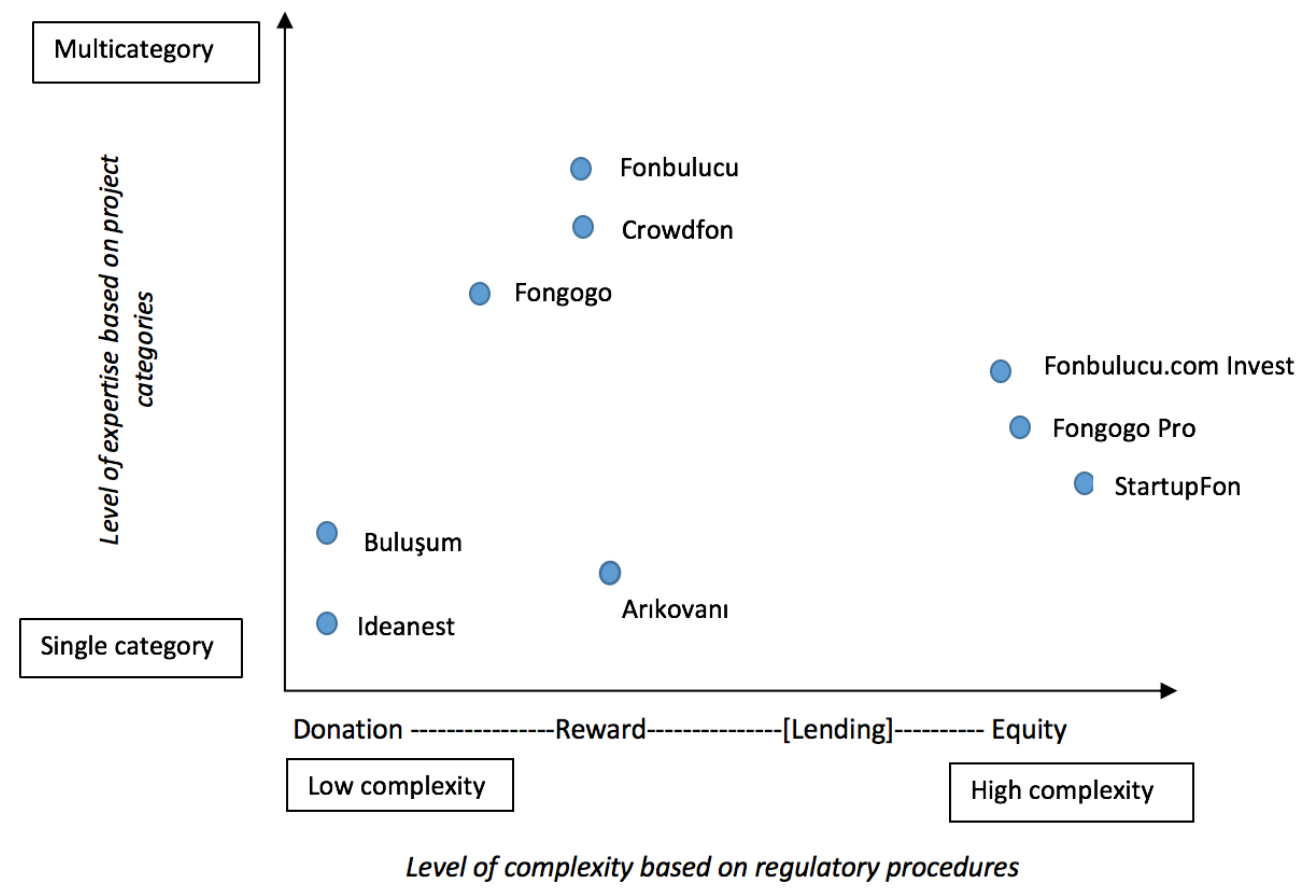

\subsection{Platforms Adopting Non-Financial Models}

Arıkovanı: This platform was launched in 2016 by Turkcell which is the most popular telecommunication company in Turkey. Reward-based model and all-or-nothing funding mechanism are adopted in this platform. This platform is an example of a vertical platform concerning the level of expertise based on project categories since it includes only technology and innovation 
focused projects with prototypes and targeting end users are accepted. As of at the end of 2018, 34 projects were successfully funded out of 66 launched initiatives and approximately TL 4,600,000 has been raised (Ertopuz, 2018). ApeX Drone project, the most successfully funded crowdfunding project in Turkey, was launched through Arıkovanı and raised TL 783,955. This crowdfunding platform is ranked number one in terms of total funding volume in Turkey.

Buluşum: This platform was launched in 2015 by Boyner Foundation where donation-based model and "keep it all" funding mechanism are used. It is a vertical platform which concentrates on social entrepreneurship and projects offering public good. Twelve projects were successfully funded out of 14 published campaigns and TL 288,300 have been collected as of today.

Crowdfon: Although Crowdfon was officially launched in 2013, it is identified as the oldest platform since it purchased the first crowdfunding platform, established in 2010, called 'Projemefon' and changed its name to Crowdfon. Reward-based model and all-or-nothing funding mechanism are adopted in this platform which represents an example of the horizontal platform since it has ten project categories including art, technology, film and video, photography, music, publishing, design, environment and mobile. Eighteen projects were successfully funded out of 185 launched initiatives and almost TL 84,000 have been raised by 2017 (Çubukçu, 2017).

Fonbulucu: Fonbulucu, launched in 2017, is a reward-based crowdfunding platform. It has multiple funding mechanisms such that 'all-or-nothing' and 'keep it all' are used by project creators. While 'all-or-nothing' campaigns are published by individuals and companies, 'keep it all' option is offered for non-profit organizations. This platform is an example of horizontal platform and located as the least specialized in the positioning map (shown in Figure 1) since it has 15 project categories including energy, animals, science and technology, design, education, environment, health, women plus, sports, culture and art, film, music, publishing and social responsibility. Concerning the project categories, science and technology have the largest percentage with $18 \%$, followed by social responsibility with $13 \%$, culture and art with $10 \%$. Eleven projects were successfully completed out of 24 published campaigns and TL 283,740 have been pledged.

Fongogo: The platform, founded in 2013, adopts both reward- and donation-based models. While reward-based crowdfunding campaigns with 'all-or-nothing' funding mechanism are launched by individuals and companies, donation-based ones with 'keep it all' funding mechanism can be used by non-profit organizations. Although it represents an example of the horizontal platform due to its wide range of project categories including environment, dance, education, film, food, culture and art, music, health, sports, design and architecture, technology and tourism, film category is the most outstanding one among all categories which constitute almost $40 \%$ of published projects. It can be seen that the platform is gaining expertise in the film category and is increasing its popularity by promoting the growth of this category. Also, Fongogo makes a significant contribution to the film industry by enabling filmmakers to realize their projects. Especially, producers of many short films and documentaries find the opportunity to attend national and international festivals and win prizes. By the end of 2018, 130 projects have been successfully completed out of 422 published campaigns, TL 2,444,599 has been raised, 12,232 people have supported a single project and there are 25,655 members in this platform. Fongogo is the largest platform in terms of quantity of campaigns launched and the number of members in Turkey.

Ideanest: This platform in which donation-based model and 'keep it all' funding mechanisms are used, was launched in 2017 by TTGV (Technology Development Foundation in Turkey). It is a pure vertical platform which focuses on technological projects offering public good. Indeed, early stage technological and innovative initiative even in idea generation and research phase can be launched in this platform. Nine projects were successfully funded out of 10 published campaigns and TL 335,154 have been collected as of today. 
Table1: Active Crowdfunding Platforms in Turkey and Their Characteristics

\begin{tabular}{|l|c|c|c|c|c|}
\hline \multicolumn{1}{|c|}{ Platform } & $\begin{array}{c}\text { Date of } \\
\text { Inception }\end{array}$ & $\begin{array}{c}\text { Crowdfunding } \\
\text { Model }\end{array}$ & $\begin{array}{c}\text { Number of Launched } \\
\text { Projects }\end{array}$ & $\begin{array}{c}\text { Number of Successfully } \\
\text { Funded Projects }\end{array}$ & Total Raised (1000 TL) \\
\hline Arıkovanı & 2016 & Reward-based & 66 & 12 & 28,600 \\
\hline Buluşum & 2015 & Donation-based & 185 & 18 & 11 \\
\hline Crowdfon & 2013 & Reward-based & 24 & 130 \\
\hline Fonbulucu & 2017 & Reward-based & 422 & 284 \\
\hline Fongogo & 2013 & Donation and & 10 & 9 \\
\hline Ideanest & 2017 & Denation-based & 335 \\
\hline
\end{tabular}

\subsection{Equity-based Crowdfunding Platforms}

As the crowdfunding market develops, a few equity-based crowdfunding platforms have been informally established and are looking forward to the finalization of the legal process of Equity-Based Crowdfunding by Capital Market Board in Turkey. These platforms are FongogoPro, Fonbulucu.com Invest and StartupFon which are expected to launch officially their operations soon.

Fongogo Pro: Fongogo Pro will operate as equity-based crowdfunding platform. The managers of Fongogo Pro have a great crowdfunding experience which comes from operating Fongogo platforms for a long time. They intend to use their current members to provide market penetration concerning this newly emerging crowdfunding model in Turkey. In addition, they get into partnerships with many seeds and early stage incubation centers, universities and angel investor networks to attract entrepreneurs, individuals, non-qualified and qualified investors. The platform believes that everyone has the opportunity to become an angel investor and therefore aims to target individuals as potential funders who want to use their savings.

Fonbulucu.com Invest: This platform is the equity-based version of Fonbulucu.com which is reward-based crowdfunding platform. The managers of this platform consider that equity-based crowdfunding democratizes financing industry from perspectives of both entrepreneurs and investors to support the collective financial system. This platform aims to offer a marketplace to bring together project creators who seek investors and funders who want to get a financial return with a small amount of capital. In fact, the platform intends to actualize a culturally traditional collective concept in helping (called 'imece') in the scope of equity-based framework and even aims to attract savings of housewives to make real the dreams of entrepreneurs. That is why this platform is located as less specialized in the positioning map (illustrated in Figure 1) among current equity-based crowdfunding platforms in Turkey.

StartupFon: This platform is launched by Istanbul Startup Angels, which is an accredited angel investment network established in 2012. The managers of the platform propose to transfer offline investor community to online settings. This may be seen as an important competitive advantage since digitalization enables traditional angel investor community to increase its effectiveness and to be able to access more successful entrepreneurs by having less operational costs without geographic constraints. This platform has a project evaluation process ranging from 3 to 6 months and if the project is accepted by at least three qualified investors, it can be launched in the platform. Therefore, this detailed due diligence process will take more time compared to other equity-based crowdfunding platforms. The platform aims to concentrate on technological projects such as software, hightech, blockchain, Al, IoT and mobile which are in their seed or early investment stage. The platform is planning to make investments to more than a hundred startups with approximately $\$ 30$ million in funding volume within 5 years. The platform has almost 250 members and targets potential angel investors and managers in traditional companies. In addition, the platform offers individuals, who have not enough knowledge about startup investment, an option called common investment funding in which certain start-ups are selected by StartupFon (Çıracı, 2019). Therefore, this platform is located in the area of less expertise project category and more sophisticated procedures in the positioning map (shown in Figure 1). 


\section{CONCLUSION}

Crowdfunding, as a novel form of funding mechanism for supporting creativity, innovation and entrepreneurship, has gained an increasing popularity. Crowdfunding market has expanded due to evolving legal arrangements around the world. Crowdfunding platforms are critical components of this market growth. This study aims to introduce key success factors that contribute to platforms in gaining competitive advantage by proposing a positioning map in an emerging market. This paper proposes two significant attributes to generate a map that demonstrates the relative positioning of crowdfunding platforms in a developing market. Crowdfunding market in Turkey is investigated as a case where entrepreneurship ecosystem has rapidly improved and legal regulations relating this novel funding system have been enacted. This study intends to make theoretical and managerial contributions to not only crowdfunding knowledge but also marketing and entrepreneurship literatures. Introducing the positioning of the crowdfunding platforms into crowdfunding literature broadens this phenomenon and contributes to the development of platforms' assessment criteria by providing better understands about crowdfunding market segments and identifying target markets of the platforms. Also, positioning map of a certain crowdfunding market presents a holistic view for the current and potential actors of the crowdfunding market including platform managers, project creators and funders. Two main features of this novel funding system are offered as dimensions of positioning map in this study: level of complexity based on regulatory procedures and level of expertise based on project categories. The first dimension has a strong relationship with crowdfunding models since regulatory arrangements are primarily applied based on crowdfunding models. Also, this dimension gives clues about motivational factors, funding mechanism, risk perception, the phase in the enterprise life cycle and amount of money required. Whereas creators who have early stage entrepreneurial projects that need less amount of capital can use platforms in the low complexity level based on regulatory procedures, funders who are willing to take high risk and also have high monetary return expectancy can be targeted by platforms in the high level of complexity. When it comes to the other dimension, platforms that serve in multicategory level (horizontal) might have more volume compared to ones that operate as less or single category (vertical) platform. However, single category platforms like Arıkovanı in Turkey might have the opportunity to build a community having similar interest (e.g. technology focused) and high level of identification within the group. It can be foreseen that the smaller crowdfunding platforms are the more expertise based on project categories they will possess and be able to distinguish themselves among other platforms in the market. Platform managers who desire to develop their positioning strategy upon gaps in the crowdfunding market by differentiating their features in order to get advantages over their rivals can benefit from the proposed positioning map analysis. Moreover, project creators, entrepreneurs or start-ups can choose the most suitable platform for their crowdfunding campaign to be able to access the proper potential supporters. Thanks to the positioning map, perception of the supporters about the platform can be managed easily and decision making processes of funders can be facilitated. For instance, if a supporter has high level of monetary return and is willing to pay a high amount of capital, he/she can engage in the appropriate crowdfunding platform on the right side of the positioning map.

This study has a few limitations. First, this study only concentrates on one crowdfunding market. Also, the positoning map cannot include all kind of crowdfunding models since lending-based crowdfunding is illegal in Turkey. Last, due to evolving regulatory crowdfunding structure in Turkey, features of the equity-based platforms, which should not officially be launched, were determined based on platforms' own web sites that are in beta version and declaration of the managers rather than collecting primary data on their crowdfunding activities. Future research might be conducted to reveal the continuing expansion of the crowdfunding economy in an emerging market since it is expected that the number of equity-based crowdfunding platforms and the total crowdfunding market size have rapidly increased as a result of developing legal regulations and growing attention of financial market actors in Turkey. In addition, further research is essential because this regulated market, which plays a role on the penetration and acceptance of donation and reward-based platforms, might have a positive impact on the increase of the number of such platforms, hence, the positioning of the existing platforms may shift depending on their strategy.

Acknowledgment: Melek Demiray gratefully acknowledges financial support from the Scientific and Technological Research Council of Turkey (TUBITAK) under the program 2214/A. 


\section{REFERENCES}

Aaker, D.A. (1996), Building Strong Brands, The Free Press, New York, NY.

Ahlers, G. K. C., Cumming, D. J., Guenther, C. and Schweizer, D. (2012). Signaling in equity crowdfunding. Retrieved from http://ssrn.com/abstract=2161587

Belleflamme, P., Lambert, T.and Schwienbacher, A. (2014). Crowdfunding: Tapping the right crowd. Journal of Business Venturing, 29(5), 585609. doi:10.1016/j.jbusvent.2013.07.003

Bradford, C. S. (2012). Crowdfunding and the Federal Securities Laws. Columbia Business Law Review, 1, 1-150.

Braet, O., Spek, S. and Pauwels, C. (2013). Crowdfunding the movies: A Business Analysis of Crowdfinanced Moviemaking in Small Geographical Markets. Journal of Media Business Studies, 10(1), 1-23. doi:10.1080/16522354.2013.11073557

Bretschneider, U., Knaub, K. and Wieck, E. (2014). Motivations for crowdfunding: What drives the crowd to invest in start-ups? Twenty Second European Conference on Information Systems.

Buysere, K. D., Gajda, O., Kleverlaan, R. and Marom, D. (2012). A framework for European crowdfund-ing. Retrieved from www.crowdfundingframework.eu

Cholakova, M.and Clarysse, B. (2015). Does the possibility to make equity investments in crowd- funding projects crowd out reward-based investments?. Entrepreneurship Theory and Practice, 145-172.

Crowdfunding Industry Report. (2013). Retrieved from http://www.buzzacott.co.uk/getattach- ment/a4e47539-1038-40c9-b90d8709e3f4e4f/crowdfunding-industry-report-1.pdf.aspx

Crowdfunding's Potential for the Developing World. (2013). infoDev, Finance and Private Sector Development Department. Washington, DC: World Bank.

Çıracı, G. (2019). Erken aşama yatırımcılık nedir? Retrieved from https://www.youtube.com/watch?v=TrKL3Mq5s9Eandfeature=youtu.be

Çubukçu, C. (2017). Kitlesel fonlama: Türkiye'deki kitlesel fonlama platformları üzerinden bir değerlendirme, Girişimcilik ve İnovasyon Yönetimi Dergisi, 6(2), 155-172.

Demiray, M. and Aslanbay, Y. (2017). The crowdfunding communities and the value of identification for sustainability of co-creation. In Crowdfunding for Sustainable Entrepreneurship and Innovation (pp. 155-174). IGI Global.

Demiray, M., Burnaz, S. and Aslanbay, Y. (2017). The crowdfunding market, models, platforms and projects. In Crowdfunding for Sustainable Entrepreneurship and Innovation (pp. 90-126). IGI Global.

Ertopuz, A. (2018) Turkcell, Girişimcileri 4,6 Milyon TI Fonla Buluşturdu Retrieved from https://www.arti49.com/turkcell-girisimcileri-46-milyontl-fonla-bulusturdu-1388334h.htm

European Commission Report (2013). Crowdfunding innovative ventures in Europe - The financial ecosystem and regulatory landscape (Final Report). Retrieved from https://ec.europa.eu/digitalagenda/en/news/crowdfunding-innovative-ventures-europe-financial-ecosystem-andregulatorylandscape-smart

Gerber, E. M., Hui, J. S. and Kuo, P. Y. (2013). Crowdfunding: Why people are motivated to post and fund Projects on crowdfunding platforms. Retrieved from http://www.juliehui.org/wp-content/uploads/2013/04/CSCW_Crowdfunding_Final.pdf

Global Entrepreneurship Index Report. (2017) Retrieved from https://thegedi.org/wp-content/uploads/dlm_uploads/2017/11/GEI-2018-1.pdf

Global Entrepreneurship Monitor Report. (2019). Retrieved from https://www.gemconsortium.org/report/50213

Hemer, J. (2011). A snapshot on crowdfunding. Working papers firms and region, No. R2/2011. Retrieved from http://hdl.handle.net/10419/52302

Heminway, J. M. and Hoffman, S. R. (2010). Proceed at your peril: crowdfunding and the securities act of 1933. Tenn. L. Rev., 78, 879.

Hooley, G., Piercy, N.F. and Nicoulaud, B. (2008), Marketing Strategy and Competitive Positioning, FT Prentice Hall, Harlow.

Kapferer, J.N. (2012), The New Strategic Brand Management, Kogan Page, London.

Keller, K.L. (2012), Strategic Brand Management, FT Prentice-Hall, Upper Saddle River, NJ.

Kirby, E. and Worner, S. (2014). Crowdfunding: An infant industry growing fast. Staff Working Paper of the International Organisation of Securities Commissions Research Department. Retrieved from http://www.memofin.fr/uploads/library/pdf/Crowd-funding-An-Infant-IndustryGrowing- Fast[1].pdf 
Kuppuswamy, V. and Bayus, B. L. (2014). Crowdfunding Creative Ideas: The Dynamics of Project Backers in Kickstarter. UNC Kenan-Flagler Research Paper. Retrieved from http://funginstitute. berkeley.edu/wp-content/uploads/2013/11/Crowdfunding_Creative_Ideas.pdf

Kuti, M. and Madarász, G. (2014). Crowdfunding. Public Finance Quarterly, 3, 355-366.

Macht, S. A. and Weatherston, J. (2014). The benefits of online crowdfunding for fund-seeking business ventures. Strategic Change, 23(1-2), 114. doi:10.1002/jsc.1955

Marom, D. and Sade, O. (2014). Are the life and death of an early stage venture indeed in the power of the tongue? Lessons from online crowdfunding pitches. Retrieved from http://www. researchgate.net/publication/256060198

Massolution's 2015 CF Industry Report (2015). Retrieved from http://www.crowdsourc- ing.org/editorial/global-crowdfunding-market-to-reach344b-in-2015-predicts-massolutions-2015cf- industry-report/45376

Meric, J., Bouiass, K. and Maque, I. (2015). More than three's a crowd... in the best interest of companies: Crowdfunding as zeitgeist or ideology? Society and Business Review, 10(1), 23-39. doi:10.1108/ SBR-09-2014-0042

Milosevic, M. (2015). Crowdfunding as an innovation booster factor and its dependence on information systems. Retrieved from https://halparis1.archives-ouvertes.fr/hal-01158238/document

Mitra, D. (2012). The role of crowdfunding in entrepreneurial finance. Delhi Business Review, 13(2), 67-72.

Mollick, E. (2014). The dynamics of crowdfunding: An exploratory study. Journal of Business Venturing, 29(1), 1-16. doi:10.1016/j.jbusvent.2013.06.005

Ordanini, A., Miceli, L., Pizzetti, M. and Parasuraman, A. (2011). Crowdfunding: Transforming customers into investors through innovative service platforms. Journal of Service Management, 22(4), 443-470. doi:10.1108/09564231111155079

Porter, M.E. (1996), “What is strategy?”, Harvard Business Review, Vol. 74 No. 6, pp. 61-78.

Startups.watch. (2019). Türkiye Girişim Ekosistemi 2018/2019 Raporu. Retrieved from https://startups.watch

Statistica. (2017). Crowdfunding volume worldwide in 2017, by type. Retrieved from https://www.statista.com/statistics/946668/globalcrowdfunding-volume-worldwide-by-type/

Technavio. (2018). Global Crowdfunding Market 2018-2022. Retrieved from https://www.technavio.com/report/global-crowdfunding-marketanalysis-share?ctrly

Unsal, S. (2017). Kitlesel Fonlama: İ̧̧ Yapma Yöntemini Değiştirecek Yeni Sistem, İstanbul, Ceres Yayınevi.

Wen, C. H. and Yeh, W. Y. (2010). Positioning of international air passenger carriers using multidimensional scaling and correspondence analysis. Transportation Journal, 7-23.

https://arikovani.com/

https://ideanest.org/

https://fonbulucu.com/

https://invest.fonbulucu.com/

https://startupfon.com/

https://www.bulusum.biz/

https://www.crowdfon.com/

https://www.fongogo.com/

https://www.fongogopro.com/

http://www.spk.gov.tr/Duyuru/Goster/20190103/0 